\title{
GENERAL PEDAGOGY
}

DOI https://doi.org/10.30525/978-9934-26-114-5-17

\section{МУЛЬТИМЕДІА ТА МЕДІАПЕДАГОГІКА У СИСТЕМІ ФАХОВОЇ ПІДГОТОВКИ ВИКЛАДАЧІВ НІМЕЧЧИНИ}

\author{
Білицька В. М. \\ PhD, старший викладач кафедри теорії практики \\ та перекладу німецької мови \\ Національний технічний університет України \\ «Київський політехнічний інститут імені Ігоря Сікорського» \\ м. Київ, Украӥна
}

У повсякденному житті нові засоби комунікації часто асоціюються з терміном «мультимедіа», а особливо у випадку залучення різних каналів сприйняття та передачі інформації. Щоразу, коли говорять про мультимедіа у педагогіці, загострюється питання мультимодального аналізу, інтерес та усвідомлення висхідної потреби в навчанні та набутті продуктивного та критичного підходу до поєднань найрізноманітніших форм та засобів. Отже, метою викладача має бути пошук шляхів формування комунікативних навичок мультимодального спілкування та закладення алгоритму самовдосконалення та звички до самостійної роботи з автентичною інформацією.

Реформуючись за світовим зразком, модернізуючись шляхом інтеграції технологій в освітній процес, прогресуючи та змінюючись під тиском зовнішніх обставин, система освіти України бере приклад 3 країн лідерів за якістю освіти. У цьому контексті вивчення світових тенденцій розвитку педагогічної освіти актуально для України не тільки з огляду на інтеграційні процеси нашої держави в європейський та загальноосвітній світовий простір, але й задля підвищення якості педагогічної освіти й таким чином здійснення якісних змін в українському суспільстві. При цьому, саме вища педагогічна освіта $є$ саме тим соціально-культурним інститутом, який покликаний забезпечити гарантоване й зорієнтоване на потреби держави виховання нової генерації громадян. Актуальність означеної проблеми, об'єктивна потреба у вивченні досвіду європейських країн-партнерів України, а саме Німеччини, зумовили вибір теми тез. 
Як стверджує резолюція постійної конференції міністрів освіти та культури федеральних земель Німеччини медіаосвіта має бути достатньо та обов'язково закріплена всіх етапах підготовки вчителів, у тому числі в рамках підвищення кваліфікації та перекваліфікації педагогів [2, с.7].

Проте у сучасній педагогічній парадигмі Німеччини підготовка вчителів є найбільшою проблемою, а особливо у контексті дистанційного та змішаного навчання [1]. Лише Свропейський університет Фленсбурга пропонує обов'язковий кредитний модуль 3 медіапедагогіки на бакалаврській програмі підготовки вчителів та у контексті професійної педагогічної освіти університету Галле-Віттенберг передбачений обов'язковий модуль «Методична та медіакомпетентності». Окрім того в Галле розроблено додатковий курс «Нове навчання 3 медіа та за допомогою них: медіапедагогіка для всіх викладацьких рівнів» із 6 модулями та 40 кредитами загалом. У Гамбурзі кредитний модуль цієї тематики $є$ вибірковим, в Потсдамському університеті лише частиною обов'язкового модуля та має назву «Зростаємо 3 новими медіа». Попри вимоги стандарту спеціальності в Бремені медіапедагогіка ще не інтегрована до педагогічної освіти. А у Нижній Саксонії немає навіть професорської посади у цій галузі в університетах, а в угоді щодо цілей та результатів діяльності, яка укладається між університетами та урядом федеральної землі, медіакомпетентність не згадується.

У Берліні елементи мультимедійного викладання не інтегровані в програму педагогічної практики в школах. У програмі педагогічної практики Гамбурга обговорюються актуальність, можливості та ризики цифрових медіа, у школах використовуються цифрові носії та перевіряється їх ефективність.У програмі середньої професійної освіти Бремена реалізація мультимедійного підходу полягає в інтеграції цифрових медіа до змісту та методу навчання та підвищення кваліфікації фахівців.

Набагато кращий вибір пропозицій щодо підвищення кваліфікації викладачів. Підвищення кваліфікації для викладачів у Берліні передбачає проходження одного рівня програми Multiplikatorenschulung und eEducation-Pass (всього 4 рівні), а у Бранденбурзі - інтегроване до концепції внутрішнього навчання на базі школі. Підвищення ролі мультимедійної компетентності та мультимедійної комунікації завдяки закріпленню мультимедійних курсів перебуває у фокусі підготовки та перепідготовки вчителів в Інституті якісного розвитку федеральної землі Мекленбург- Передня Померанія (Institut für Qualitätsentwicklung Mecklenburg-Vorpommern). Для підвищення кваліфікації викладачів 72 
Інститут якісного розвитку федеральної землі Шлезвіг-Гольштейн пропонує навчальний тренінг з медіапедагогіки у школі.

Здійснивши педагогічну розвідку у сферу медіаосвіти та медіапедагогіки Німеччини, ми дійшли висновку, що порушена проблема потребує подальшого опрацювання та створення системи медіапедагогічних знань 3 метою їх практичної та цілісної інгерації у систему підготовки та перепідготовки вчителів в Україні. Знання як окремих медіа ресурсів, так і їх мультимодальної взаємодії є необхідним, навіть якщо освітні плани насправді жодним чином не згадують мультимодальність та медіапедагогіку як термін.

\section{Література:}

1. Kammerl R., Keinath J., Lee J., Kramer M., Schwedler A. Ist-Stand-Analyse der Medienkompetenzförderung in den Bundesländern: Berlin, Brandenburg, Bremen, Hamburg, MecklenburgVorpommern, Niedersachsen, Sachsen-Anhalt und Schleswig-Holstein. URL: https://www.ew.uni-hamburg.de/einrichtungen/ew1/medienpaedagogik-aesthetische-bildung/medienpaedagogik/dokumente/darstellungdes-ist-standes.pdf (дата звернення 07.07.2021).

2. KMK, Kultusministerkonferenz (2012): Medienbildung in der Schule. Beschluss der Kultusministerkon-ferenz vom 08.03. 2012. URL: https://www.kmk.org/fileadmin/veroeffentlichungen_beschluesse/ 2012/2012_03_08_Medienbildung.pdf (дата звернення 07.07.2021).

DOI https://doi.org/10.30525/978-9934-26-114-5-18

\section{ОСОБИСТІСТЬ ТА ОСОБЛИВОСТІ ЇЇ ВИЯВУ}

\section{Горнар I. I.}

магістрант кафедри педагогіки та менеджменту освіти Центральноукраїнський державний педагогічний університет імені Володимира Винниченка м. Кропивницький, Україна

Особистість розуміємо як цілісність соціальних властивостей людини, продукт суспільного розвитку і залучення індивіда до системи соціальних відносин за допомогою активної предметної діяльності і спілкування [6]. 